Chem. Chem. Technol., 2021,

Chemical

Vol. 15, No. 1, pp. 61-73

Technology

\title{
STATE OF THE ART IN THE PRODUCTION OF CHARCOAL: A REVIEW
}

\author{
Serhiy Pyshyev ${ }^{1}$, Denis Miroshnichenko ${ }^{2,}{ }^{凶}$ Ivan Malik $^{2}$, \\ Aquilino Bautista Contreras ${ }^{3}$, Nader Hassan $^{4}$, Ahmed Abd ElRasoul $^{4}$
}

https://doi.org/10.23939/chcht15.01.061

\begin{abstract}
The use of charcoal (CC) for various industries was analysed; the modern ideas about the factors influencing the process of obtaining $\mathrm{CC}$ were considered. The effect of raw materials nature (wood or agricultural wastes) and their characteristics (size, physical properties, chemical composition), as well as carbonization temperature, heating rate, oxygen level and pressure on the yield and quality of $\mathrm{CC}$ was described. The existing technologies for charcoal production were analyzed; they were classified according to the type of heating initiation and temperature maintenance during the carbonization process. The Lambiotte, DPC and Carbonex technologies were considered.
\end{abstract}

Keywords: charcoal, bio resources, technology of charcoal production, kiln, quality.

\section{Introduction}

Charcoal, the main product from carbonization (slow pyrolysis) of biomass, has a wide range of applications in various industries, which among others include direct combustion of charcoal as solid fuel, gasification of charcoal for synthesis gas production, purification of flue gases, desulfurization gases or water, and use as a reductant alternative to fossil carbon in metallurgical industry, etc. [1-5].

In 2017, 51.2 million tons (Mt) of wood charcoal were produced globally, up from $37.0 \mathrm{Mt}$ in 2000 [6]. From 1993 to 2017, the largest average amounts of charcoal were produced annually in Africa (24.6 Mt), with

\footnotetext{
${ }^{1}$ Lviv Polytechnic National University,

12, Bandera St., 79013 Lviv, Ukraine

${ }^{2}$ National Technical University "Kharkiv Polytechnic Institute",

2, Kirpychova St., 61002 Kharkiv, Ukraine

${ }^{3}$ Carbosur, Calle Mexico F12, Parque Industrial Maquilador Oaxaca 2000,

Magdalena Apasco Etla, C.P. 68226, Oaxaca, Mexico

${ }^{4}$ Nader Group Engineering,

Rasta Hotel, Unit 728, P.C. 42512, Port Said, Egypt

$凶$ dvmir79@gmail.com

(C) Pyshyev S., Miroshnichenko D., Malik I., Bautista Contreras A., Hassan N., Abd ElRasoul A., 2021
}

$57 \%$ of the global production, followed by the Americas ( $23 \%$, mostly Latin America), and Asia (18 \%; Fig. 1a).

In Europe and North America, charcoal is used extensively as leisure fuel (e.g., for barbeques) [7, 8]. $40 \%$ of the charcoal used in Europe is imported from Africa, with Nigeria, Egypt, Namibia, and South Africa as key players $[7,9,10]$. Intra-European charcoal trade also exists, with Ukraine, Lithuania, and Latvia as main suppliers to Belgium, Germany, and Poland [7, 10].

Global charcoal imports and exports are estimated at US\$1.16B [11]. From 1993-2017, the world's top 10 charcoal-producing countries (Fig. 1b) generated an average of $24.5 \mathrm{Mt}$ of charcoal annually, more than $50 \%$ of which were produced by Brazil, Nigeria, and Ethiopia [6]. The US\$784M charcoal exports [12] are mainly sourced from the tropical rainforests of Indonesia (Fig. 1c). Incidentally, some of the countries with low risk to energy security, defined as the continuous availability of energy at an affordable price, including Germany, Japan, France, and the UK $[13,14]$, are among the top importers of charcoal (Fig. 1d).

In various countries of the world, normative documentation has been developed and used, which regulates the values of separate indicators of the quality of charcoal.

The EN 1860-2:2005 Appliances, solid fuels and firelighters for barbequing - Part 2: Barbecue charcoal and barbecue charcoal briquettes - Requirements and test methods specify the requirements and test methods for charcoal and charcoal briquettes for use in BBQ appliances (Table 1).

Moreover, in Inadmissible additions there is information that Microscopic analysis should not detect more than 10 particles in 1000 particles of any substance which is not normally found after the distillation of wood to produce wood charcoal or in permissible binder in wood charcoal briquettes.

The requirements specified to the quality of charcoal according to the national standards are represented in Table 2. 
Charcoal is manufactured from wood according national standard Wood raw material for pyrolysis and charring. Specifications:
A - Charcoal from wood of group 1 (Table 3);

B - Charcoal from blends of wood of group 1 and 2;

C-Charcoal from blends of wood of group 1, 2 and 3 .

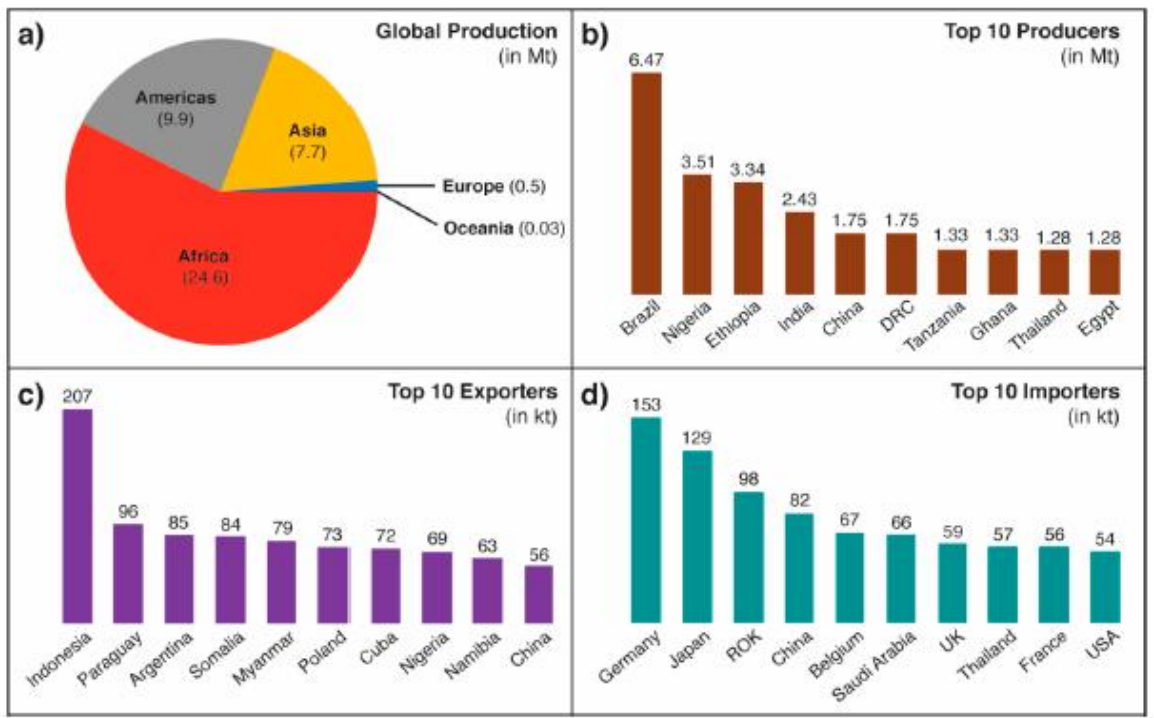

Fig. 1. Global charcoal production and trade (1993-2017) [6]

\section{Requirements for charcoal and charcoal briquettes}

\begin{tabular}{|c|c|c|}
\hline Index & Charcoal & Charcoal briquettes \\
\hline Fixed carbon & Minimum $75 \%$ & Minimum $60 \%$ \\
\hline Ash & Not exceed $8 \%$ & Maximum $18 \%$ \\
\hline Total moisture & Not exceed $8 \%$ & Shall not be above $8 \%$ \\
\hline Granulation & $\begin{array}{l}\text { The particle size shall be } \\
0 \mathrm{~mm} \text { to } 150 \mathrm{~mm} \\
\text { - No more than } 10 \% \text { may exceed } 80 \mathrm{~mm} \text { in size; } \\
\text { - At least } 80 \% \text { shall be greater than } 20 \mathrm{~mm} \text {; } \\
-0-10 \mathrm{~mm} \text { shall not exceed } 7 \%\end{array}$ & $\begin{array}{c}\text { The granules less than } 20 \mathrm{~mm} \text { shall } \\
\text { not be exceed } 10 \%\end{array}$ \\
\hline Volatiles & $\begin{array}{l}\text { Must be carried out to allow determination of fixed } \\
\text { carbon }\end{array}$ & \\
\hline Bulk density & At least $130 \mathrm{~kg} / \mathrm{m}^{3}$ & \\
\hline
\end{tabular}

Table 2

\section{Requirements for charcoal}

\begin{tabular}{|c|c|c|c|c|c|}
\hline \multirow{3}{*}{ Index } & \multicolumn{5}{|c|}{ Grade } \\
\hline & \multicolumn{2}{|c|}{ A } & \multicolumn{2}{|c|}{$\mathrm{B}$} & \multirow{2}{*}{$\mathrm{C}$} \\
\hline & Extra & First & First & Second & \\
\hline Apparent density, $\mathrm{g} / \mathrm{cm}^{3}$, not less & 0.37 & 0.37 & \multicolumn{3}{|c|}{-} \\
\hline Ash, $\%$, not more & 2.5 & 3.0 & 2.5 & 3.0 & 4.0 \\
\hline Fixed carbon, $\%$ not less & 90 & 78 & 88 & 77 & 67 \\
\hline Total moisture, $\%$ not more & 6 & 6 & 6 & 6 & 6 \\
\hline \multirow{3}{*}{$\begin{array}{l}\text { Granulation, \%, not more } \\
<25 \mathrm{~mm} \\
<12 \mathrm{~mm}\end{array}$} & & & & & \\
\hline & 5 & 5 & - & - & - \\
\hline & 5 & 5 & 7 & 7 & 7 \\
\hline Mass fraction of smut, $\%$, not more & Absence & 2 & Absence & 2 & 2 \\
\hline Bulk density, $\mathrm{g} / \mathrm{dm}^{3}$, not more & 210 & 210 & \multicolumn{3}{|c|}{ - } \\
\hline
\end{tabular}


Wood raw materials

\begin{tabular}{|c|c|c|c|}
\hline \multirow{2}{*}{ Process } & \multicolumn{2}{|c|}{ Group } & 3 \\
\cline { 2 - 4 } & 1 & 2 & - \\
\hline Pyrolysis & $\begin{array}{c}\text { birch, beech, ash, hornbeam, elm, } \\
\text { oak, maple }\end{array}$ & $\begin{array}{c}\text { aspen, alder, linden, } \\
\text { poplar, willow }\end{array}$ & $\begin{array}{c}\text { aspen, alder, linden, } \\
\text { poplar, willow }\end{array}$ \\
\hline Charring & $\begin{array}{c}\text { birch, beech, ash, hornbeam, elm, } \\
\text { oak, maple }\end{array}$ & pine, spruce, cedar, fir, larch & ( \\
\hline
\end{tabular}

\section{The Raw Materials and Production Conditions}

The raw material for carbonization, its gathering and preparation constitute the single most important aspect of charcoal manufacture no matter what method of carbonization is used. Raw materials are divided into two groups: those derived from trees, i.e. wood in some form or other and those derived from agriculture, the so-called agricultural residues.

The mechanical strength of charcoal depends on its lump or powder and also on the raw material. To possess a high crushing strength the raw material must contain lignin and extractives. These substances when carbonized give strength to be charcoal. High strength charcoal requires wood or nut shells as raw material. If lump charcoal is needed then wood is practically the only material though coconut shells produce strong charcoal suited for gas absorption purposes in a size adequate for this application.

The conventional charcoal production consumes a large amount of energy due to the prolonged heating time and cooling time which contribute to the process completing in one to several days. Wood pyrolysis consists of both endothermic and exothermic reactions, as well as the decomposition of different components at different temperature range (473-733 K for hemicellulose; 513-623 K for cellulose and 553-773 K for lignin).

Data for European hardwoods that show the marked rise in heat and electricity use, when the moisture content increases, are presented in Table 4 [15].

The sharp rise in energy consumption when the raw material moisture content rises is not the only problem. Increased moisture input to the system reduces the installed capacity of the plant and slows down production. Moreover, it is important to keep the moisture content of the wood entering the retort to around $30 \%$ or less. Otherwise the gas coming from the retort is difficult to burn and will not produce the hot inert heating gas needed.

The purpose of the study reported in [16] was to determine some properties of wood and charcoal from six clones of Eucalyptus (Table 5).
An average heating rate was $1.67 \mathrm{~K} / \mathrm{min}$, the initial temperature was $373 \mathrm{~K}$, the final temperature was $723 \mathrm{~K}$, and it remained stable for a period of $60 \mathrm{~min}$ with a total carbonization of $4.5 \mathrm{~h}$. Heating rate of $1.67 \mathrm{~K} / \mathrm{min}$ provides a charcoal with high mechanical strength, because if a heating rate was used, it would cause the disruption of cells due to the rapid exit of water and gas, causing the cracking of charcoal and generation of fines. Table 6 shows the quality of charcoal from eucalyptus clones.

According to research results, several properties of wood should be considered together for the selection of clones for charcoal production. However, basic density and chemical composition of wood, especially high contents of lignin and low contents of extractives, are the properties that had more influence on charcoal yield and its quality.

The heating value (HHV) can be estimated using the model developed by Nhuchhen and Afzal [17], which has a good prediction accuracy within the error bar of $\pm 10 \%$. The correlation can be expressed as:

$$
\mathrm{HHV}=0.0352 \mathrm{FC}+0.1846 \mathrm{VM}
$$

Based on the result of the proximate analysis, the elemental composition of common organic elements such as carbon $(\mathrm{C})$, hydrogen $(\mathrm{H})$, and oxygen $(\mathrm{O})$ can be estimated using Eqs. (2)-(4). These were evaluated at an estimate of $95 \%$ confidence level [18]:

$$
\begin{gathered}
\mathrm{C}=0.637 \mathrm{FC}+0.455 \mathrm{VM} \\
\mathrm{H}=0.052 \mathrm{FC}+0.062 \mathrm{VM} \\
\mathrm{O}=0.304 \mathrm{FC}+0.476 \mathrm{VM}
\end{gathered}
$$

The formation of charcoal under laboratory conditions has been studied and the following stages in the conversion process have been recognized [15]:

- at 293-383 K the wood absorbs heat as it is dried giving off its moisture as water vapor (steam). The temperature remains at or slightly above $373 \mathrm{~K}$ until the wood is bone dry;

- at $383-543 \mathrm{~K}$ thefinal traces of water are given off and the wood starts to decompose giving off some carbon monoxide, carbon dioxide, acetic acid and methanol. Heat is absorbed;

- at 543-563 K the exothermic decomposition of the wood starts. Heat is evolved and breakdown continues spontaneously providing the wood is not 
cooled below this decomposition temperature. Mixed gases and vapors continue to be given off together with some tar;

- at $563-673 \mathrm{~K}$ the breakdown of the wood structure continues, the vapors given off comprise the combustible gases carbon monoxide, hydrogen and methane together with carbon dioxide gas and the condensable vapors: water, acetic acid, methanol, acetone, etc. and tars which begin to predominate as the temperature rises;

- at 673-773 K: the transformation of the wood to charcoal is practically complete at $673 \mathrm{~K}$. The charcoal at this temperature still contains appreciable amounts of tar, perhaps $30 \mathrm{wt} \%$ trapped in the structure. This soft burned charcoal needs further heating to drive off more of the tar and thus raise the fixed carbon content of the charcoal to about $75 \%$ which is normal for good quality commercial charcoal.
To drive off this tar the charcoal is subjected to further heat inputs to raise its temperature to about $773 \mathrm{~K}$, thus completing the carbonization stage.

Three main stages requiring heat inputs in charcoal making are:

- the drying of the wood;

- raising the temperature of the oven dry wood to $543 \mathrm{~K}$ to start spontaneous pyrolysis, which itself releases heat;

- final heating to approx. $773-823 \mathrm{~K}$ to drive off tar and increase the fixed carbon to an acceptable figure for good commercial charcoal.

According to [19], eucalyptus microtheca heartwood yielded the highest amount of charcoal $(44,32$, 28 and $26 \%$ ) at the temperatures of $723,923,1123$ and $1323 \mathrm{~K}$, respectively, in comparison to E. camaldulensis (Fig. 2).

Table 4

Effect of wood moisture content on energy use [15]

\begin{tabular}{|c|c|c|c|}
\hline Moisture, $\%$ & Energy used, $\mathrm{MJ} / \mathrm{m}^{3}$ & Circulating gas, $\mathrm{m}^{3}$ & Electricity, $\mathrm{kWh}$ \\
\hline 5 & 35 & 210 & 2.5 \\
\hline 10 & 40 & 270 & 3.2 \\
\hline 15 & 154 & 490 & 4.4 \\
\hline 20 & 293 & 770 & 5.2 \\
\hline 25 & 460 & 1050 & 7.2 \\
\hline 30 & 648 & 1400 & 9.0 \\
\hline
\end{tabular}

Table 5

Quality of eucalyptus clones [16]

\begin{tabular}{|c|c|c|c|c|c|c|c|}
\hline \multirow{2}{*}{ Clone } & Genetic material & \multirow{2}{*}{ Ash, \% } & Basic density, g/cm & \multirow{2}{*}{$\mathrm{HHV}, \mathrm{MJ} / \mathrm{kg}$} & \multicolumn{3}{|c|}{ Chemical composition, \% } \\
\cline { 5 - 9 } & & & & & $\begin{array}{c}\text { Cellulose+ } \\
\text { hemicellulose }\end{array}$ & Lignin & \multirow{2}{*}{ Extractives } \\
\hline 1 & Eucalyptus camaldulensis & 0.16 & 0.53 & 19.07 & 65.25 & 30.29 & 4.30 \\
\hline 2 & Eucalyptus urophylla Hibrid & 0.14 & 0.55 & 19.04 & 63.46 & 31.42 & 4.97 \\
\hline 3 & Eucalyptus grandis Hibrid & 0.12 & 0.58 & 19.03 & 65.90 & 29.82 & 4.15 \\
\hline 4 & Eucalyptus urophylla Hibrid & 0.10 & 0.55 & 19.10 & 66.42 & 28.78 & 4.70 \\
\hline 5 & Eucalyptus urophylla & 0.11 & 0.59 & 18.87 & 65.44 & 29.68 & 4.77 \\
\hline 6 & Eucalyptus camaldulensis & 0.18 & 0.56 & 19.24 & 66.36 & 30.37 & 3.10 \\
\hline
\end{tabular}

Table 6

Quality of charcoal from eucalyptus clones [16]

\begin{tabular}{|c|c|c|c|c|c|c|}
\hline \multirow{2}{*}{ Clone } & \multirow{2}{*}{$\begin{array}{c}\text { Gravimetric } \\
\text { yield, } \%\end{array}$} & \multirow{2}{*}{$\begin{array}{c}\text { Bulk density, } \\
\mathrm{kg} / \mathrm{m}^{3}\end{array}$} & \multirow{2}{*}{$\mathrm{HHV}, \mathrm{MJ} / \mathrm{kg}$} & \multicolumn{3}{|c|}{ Proximate analysis, $\%$} \\
\hline & & & & Ash, \% & VM & $\mathrm{FC}$ \\
\hline 1 & 34.95 & 0.36 & 31.04 & 0.35 & 26.72 & 72.93 \\
\hline 2 & 34.40 & 0.38 & 31.41 & 0.33 & 24.76 & 74.91 \\
\hline 3 & 34.90 & 0.39 & 31.02 & 0.35 & 25.79 & 73.86 \\
\hline 4 & 34.30 & 0.37 & 29.60 & 0.41 & 25.74 & 73.86 \\
\hline 5 & 35.40 & 0.41 & 31.89 & 0.36 & 26.08 & 73.56 \\
\hline 6 & 35.70 & 0.41 & 31.60 & 0.64 & 24.23 & 75.13 \\
\hline
\end{tabular}




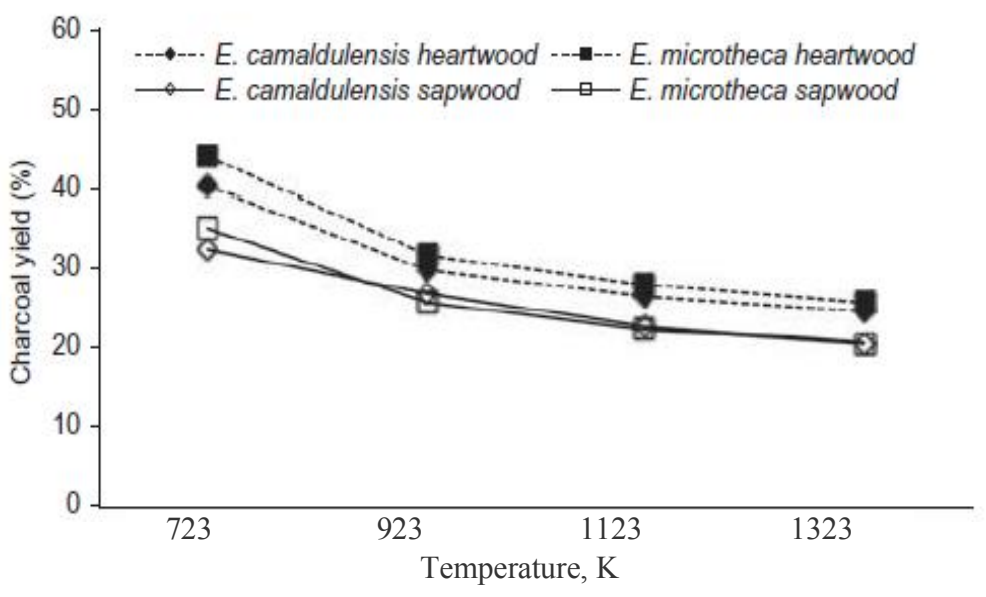

Fig. 2. Charcoal yield from sapwood and heartwood of E. camaldulensis and E. microtheca at different temperatures [19]

Oyedun et al. [20] proposed a multistage pyrolysis, which is an approach to carry out pyrolysis with multiple heating stages so as to gain certain processing benefits. It was proposed a three-stage approach, which included rapid stepwise heating stage to a variable target temperatures of 523, 573, 623 and $673 \mathrm{~K}$, slow and gradual heating stage to a final temperature of $673 \mathrm{~K}$ and adiabatic with a cooling stage. The multistage pyrolysis process can save $30 \%$ of energy and the processing time by using a first temperature target of $573 \mathrm{~K}$ and heating rate of $5 \mathrm{~K} / \mathrm{min}$ to produce a fixed-carbon yield of $25.73 \%$ as opposed to the base with a fixed-carbon yield of $23.18 \%$.

The long cooling time of charcoal produced from eucalyptus pyrolysis is due in part to the heat generation in oxidation reactions at low temperatures. The intensity of these reactions depends on complex interactions between the interstitial gas and the solid matrix. It was evidenced that the rate of oxygen consumption increases with a charcoal temperature at rates that depend on the initial concentration of $\mathrm{O}_{2}$. The beginning of the oxidation reactions was observed at $340 \mathrm{~K}$ in atmospheres with $20.9 \% \mathrm{O}_{2}$. The overall activation energy for the selfheating phenomenon was $17.790 \mathrm{~J} / \mathrm{mol}$ and its intensity was increased with the temperature and $\mathrm{O}_{2}$ concentration [21].

The effect of biomass heating rate, purging gas flow and particle size on the yield of charcoal from pine wood was quantified in a series of pyrolysis experiments using a thermos-gravimetric apparatus [22]. Temperaturetime curves obtained during the heating of biomass showed that the pyrolysis reactions became exothermic at about $623 \mathrm{~K}$. Increasing the flow of inert carrier gas through the biomass sample resulted in a decrease in the charcoal yield and a faster rate of biomass decomposition. At zero gas flow the charcoal yield is independent of particle size. As gas flow through the sample is increased the yield of charcoal is increasingly dependent on the increasing particles size.

Increasing the wood heating rate from 0.11 to $10 \mathrm{~K} / \mathrm{min}$ resulted in the decreasing charcoal yield. The period of fast biomass decomposition shifted to higher temperatures and the start of decomposition occurred at higher temperatures. These results indicate that low temperature reactions of charcoal formation are favored by low heating rates and the initial charcoal acts as a catalyst for primary biomass decomposition. Lower heating rates are also associated with the increased retention of pyrolysis vapors in the biomass which results in increased production of secondary charcoal and increased charcoal yield.

Kluska et al. [23] described the results of corncobs carbonization for the preparation of barbeque charcoal and combustion characteristics of corncob char. The characteristics of corncob are presented in Table 7.

Table 7

Proximate and ultimate analysis of corncob waste [23]

\begin{tabular}{|c|c|c|c|c|c|c|c|c|c|}
\hline \multicolumn{4}{|c|}{ Proximate analysis, \% } & \multicolumn{5}{c|}{ Ultimate analysis, \% } & \multirow{2}{*}{ HHV, MJ/kg } \\
\hline M & VM & Ash & FC & C & H & N & S & O & \\
\hline 10.2 & 56.77 & 1.37 & 41.86 & 45.69 & 6.18 & 5.65 & 0.04 & 41.65 & 16.2 \\
\hline
\end{tabular}


Experimental results concerning the influence of carbonization temperature on char yield show that the average yield of the obtained char decreased with the temperature from $43.1 \%$ at $573 \mathrm{~K}$ to $22.7 \%$ at $973 \mathrm{~K}$ (Fig. 3).

The range from 573 to $773 \mathrm{~K}$ represents the main stage of carbonization, where the greatest mass loss of the sample can be observed. This is related to the decomposition of cellulose and hemicellulose, the contents of which in a cob are 34-37\% and 35-39\%, respectively $[24,25]$. The retardation of the carbonization process above $773 \mathrm{~K}$ is associated with the thermal decomposition of lignin, which content is approximately $15-17 \%$ [25]. Moreover, experimental results show that the higher heating value increased from 27.5 to $31.5 \mathrm{MJ} / \mathrm{kg}$ along with the increase in carbonization temperatures from 573 to $973 \mathrm{~K}$. It can be seen that the heating value of corncob char at the first stage rapidly increased, then decreased above $773 \mathrm{~K}$. At the first stage, pyrolytic gases with calorific values lower than that of the char were released from the fuel particle due to the thermal composition of cellulose and hemicellulose, with a simultaneous increase in a fixed carbon content. The

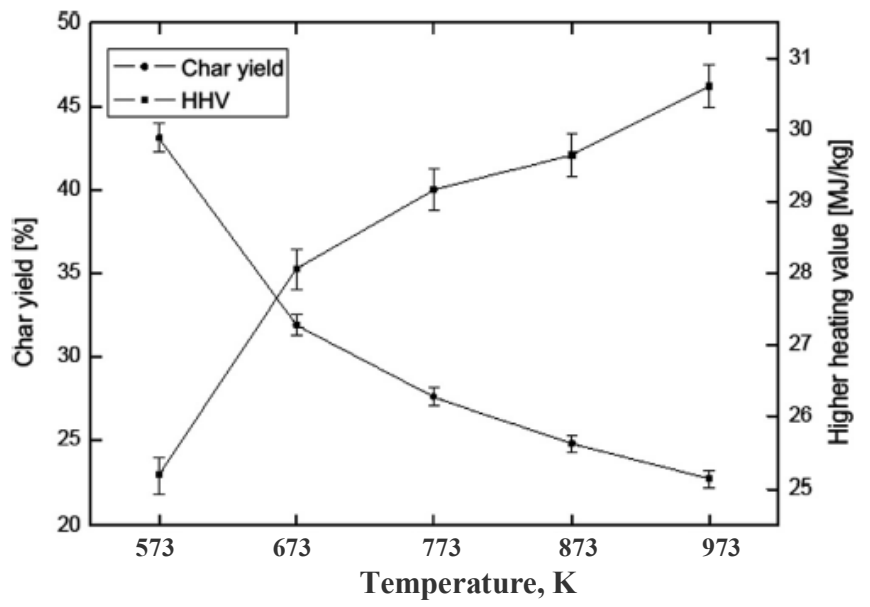

Fig. 3. Influence of the temperature of carbonization of corncobs on product yields and HHV [23] yield of the char decreased but energy density increased along with the carbonization temperature. Above $773 \mathrm{~K}$ the pyrolysis process slowed; the pyrolytic gases and tar were removed and the rate of calorific value increase decreased.

Fig. 4 presents the results of the proximate analysis of char obtained from the carbonization of corncobs at different process temperatures.

An increase in carbonization temperature caused the increase in the fixed carbon content, from $54.9 \%$ at $573 \mathrm{~K}$ to $86.7 \%$ at $973 \mathrm{~K}$, with a simultaneous decrease in volatile matter content from 40.2 to $8.3 \%$. The ash content in the char increased from $1.4 \%$ at $573 \mathrm{~K}$ to $4.9 \%$ at $973 \mathrm{~K}$. The variations in the volatile matter and fixed carbon yields show that, above $873 \mathrm{~K}$, fixed carbon yield increased about $2 \%$ and volatile yield decreased about $2 \%$, indicating that the carbonization process slowed.

Table 8 presents elemental and calculated $\mathrm{O} / \mathrm{C}$ and $\mathrm{H} / \mathrm{C}$ for corncob char resulting from different temperatures of carbonization. The results show that the hydrogen and oxygen contents decreased with increased carbonization temperatures; this was caused by the breaking of the weaker bonds within the structure of the char.

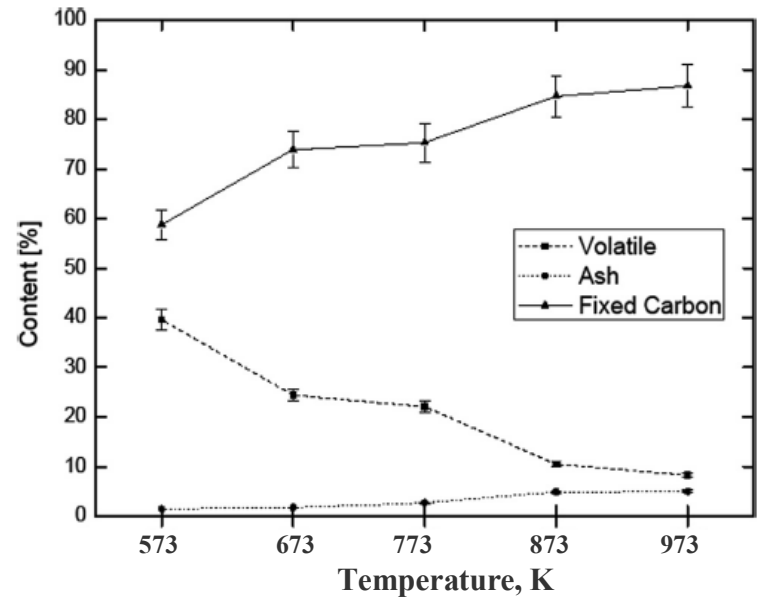

Fig. 4. Proximate analysis of char from corncob carbonization at various process temperatures [23]

Table 8

Ultimate analysis of corncob char produced at different carbonization temperatures [23]

\begin{tabular}{|c|c|c|c|c|c|c|}
\hline \multirow{2}{*}{ Temperature, $\mathrm{K}$} & \multicolumn{6}{|c|}{ Ultimate analysis, $\%$} \\
\hline & $\mathrm{C}$ & $\mathrm{H}$ & $\mathrm{N}$ & $\mathrm{O}$ & $\mathrm{H} / \mathrm{C}$ & $\mathrm{O} / \mathrm{C}$ \\
\hline 573 & 69.18 & 4.50 & 5.42 & 19.98 & 0.78 & 0.22 \\
\hline 673 & 73.01 & 3.55 & 4.40 & 18.12 & 0.58 & 0.19 \\
\hline 773 & 80.63 & 3.15 & 5.94 & 9.36 & 0.47 & 0.09 \\
\hline 873 & 82.96 & 2.43 & 4.59 & 9.11 & 0.35 & 0.08 \\
\hline 973 & 85.25 & 1.83 & 3.99 & 8.01 & 0.26 & 0.07 \\
\hline
\end{tabular}


The decrease in oxygen and hydrogen content is associated with the emission of both gaseous and liquid (volatile) pyrolysis products. The decrease in hydrogen content can be divided into two stages: firstly, mainly associated with the formation of liquid products, and the second, in which the reduction of the hydrogen content in the char was connected with the pyrolytic gas production. The first stage, which concerned dehydration and the formation of volatile products (anhydrosugars and furanic compounds) from cellulose, decomposition of hemicellulose along with the formation of anhydrosugars, aldehydes, ketones and emissions of phenolic derivatives from lignin decomposition, occurred at temperatures up to $723-773 \mathrm{~K}$. At the second stage, in addition to the emission of phenyl derivatives from lignin, demethylation, demethoxylation, and dehydrogenation reactions took place at the temperature of above $873 \mathrm{~K}$ in all three main lignocellulosic biomass components. The decrease in the oxygen content is associated with a number of reactions, starting with all processes classified in the paper and continuing to the first stage of reduction of hydrogen content in the solid fraction. The second main source of oxygen reduction is its emission in the form of carbon monoxide and carbon dioxide. Among the processes the products of which are the indicated gases, the most important are the decarboxylation of $-\mathrm{COOH}$ and $\mathrm{O}$ acetyl groups and the cracking and reforming of groups of $-\mathrm{COOH}, \mathrm{C}=\mathrm{O}, \mathrm{C}-\mathrm{H}$, and $\mathrm{C}-\mathrm{O}-\mathrm{C}$ bonds.

The results also affect the atomic ratios of $\mathrm{H} / \mathrm{C}$ and $\mathrm{O} / \mathrm{C}$. The $\mathrm{H} / \mathrm{C}$ atomic ratio for corncobs decreased from 1.62 to 0.26 at a carbonization temperature of $973 \mathrm{~K}$; the $\mathrm{O} / \mathrm{C}$ atomic ratio for corncobs decreased from 0.66 to 0.07 at $973 \mathrm{~K}$. According to the literature [26-28], the decrease in the $\mathrm{H} / \mathrm{C}$ and $\mathrm{O} / \mathrm{C}$ atomic ratios leads to the increase in aromatic and carbonaceous content and result in a reduced hydrophilic char surface.

The elemental composition of char, as well as its properties, depends on final carbonization temperatures. At high temperatures the carbon content increases dramatically. The yield, water absorbency and hydrogen content decrease rapidly as the carbonization temperature increases. The yield is quite low at higher temperatures and hence the production of charcoal at these temperatures is only of theoretical interest [29]. Table 9 shows the yields of gas, char, tar, and condensed liquid from the biomass samples at different carbonization temperatures.

Table 9

Yields of charcoal, liquid (tar and condensed organics), and gas from the biomass samples at carbonization temperatures [29]

\begin{tabular}{|c|c|c|c|c|c|c|c|}
\hline \multirow{2}{*}{ Sample } & \multicolumn{7}{|c|}{ Temperature, K } \\
\hline & 823 & 923 & 1023 & 1123 & 1223 & 1323 & 1423 \\
\hline \multicolumn{8}{|c|}{ Spruce wood } \\
\hline Charcoal & 38.3 & 32.6 & 29.4 & 27.8 & 26.1 & 25.7 & 25.4 \\
\hline Gas & 19.2 & 20.2 & 24.9 & 35.8 & 56.5 & 59.1 & 66.7 \\
\hline Liquid & 34.3 & 37.8 & 38.5 & 29.0 & 12.6 & 12.8 & 6.4 \\
\hline Tar & 10.2 & 9.4 & 7.2 & 7.4 & 4.8 & 2.4 & 1.5 \\
\hline \multicolumn{8}{|c|}{ Beech wood } \\
\hline Charcoal & 35.6 & 29.7 & 26.2 & 24.7 & 23.6 & 23.0 & 22.7 \\
\hline Gas & 18.0 & 22.3 & 25.4 & 37.3 & 59.1 & 62.5 & 69.8 \\
\hline Liquid & 36.2 & 38.4 & 40.4 & 40.9 & 13.0 & 12.3 & 6.2 \\
\hline Tar & 10.2 & 9.6 & 8.0 & 7.1 & 4.3 & 2.2 & 1.3 \\
\hline \multicolumn{8}{|c|}{ Ailantus wood } \\
\hline Charcoal & 35.7 & 30.1 & 26.6 & 24.9 & 23.6 & 23.2 & 22.8 \\
\hline Gas & 18.1 & 22.3 & 25.3 & 36.6 & 59.3 & 62.3 & 69.5 \\
\hline Liquid & 36.1 & 37.9 & 40.2 & 31.3 & 14.6 & 12.4 & 6.3 \\
\hline Tar & 10.1 & 9.7 & 7.9 & 7.2 & 4.5 & 2.1 & 1.4 \\
\hline \multicolumn{8}{|c|}{ Hazelnut shells } \\
\hline Charcoal & 42.6 & 38.4 & 34.8 & 32.5 & 31.3 & 30.9 & 30.7 \\
\hline Gas & 17.8 & 22.4 & 30.6 & 36.4 & 49.8 & 50.5 & 52.1 \\
\hline Liquid & 27.9 & 28.6 & 27.0 & 22.6 & 16.3 & 16.1 & 15.5 \\
\hline Tar & 11.7 & 10.6 & 7.6 & 8.5 & 3.6 & 2.4 & 1.7 \\
\hline \multicolumn{8}{|c|}{ Walnut shell } \\
\hline Charcoal & 43.5 & 38.6 & 34.0 & 33.1 & 31.9 & 31.5 & 31.0 \\
\hline Gas & 17.3 & 23.1 & 30.5 & 38.7 & 47.8 & 50.2 & 51.7 \\
\hline Liquid & 27.7 & 27.9 & 28.1 & 21.6 & 16.5 & 16.1 & 15.6 \\
\hline Tar & 11.5 & 10.4 & 7.4 & 6.6 & 3.8 & 2.2 & 1.7 \\
\hline
\end{tabular}


It is obvious that the most interesting temperature range for the production of the pyrolysis products is between 625 and $775 \mathrm{~K}$. The charcoal yield decreased gradually from 43.5 to $31 \%$ for the walnut shell and from 38.3 to $25.4 \%$ for the spruce wood with an increase of temperature from 550 to $1150 \mathrm{~K}$. The charcoal yield decreases as the temperature increases. The ignition temperature of charcoal increases as the carbonization temperature increases.

Slow pyrolysis of pequi seeds $(2 \mathrm{~K} / \mathrm{min}, 703 \mathrm{~K})$ produced up to $40 \%$ of high-grade charcoal with $60 \%$ of fixed carbon, $43 \%$ of bio-oil, and $16 \%$ of light gases. The overall energy extraction efficiency was estimated as $61 \%$, based on the higher heating value of wet pequi seeds. The investigation confirmed that waste pequi could

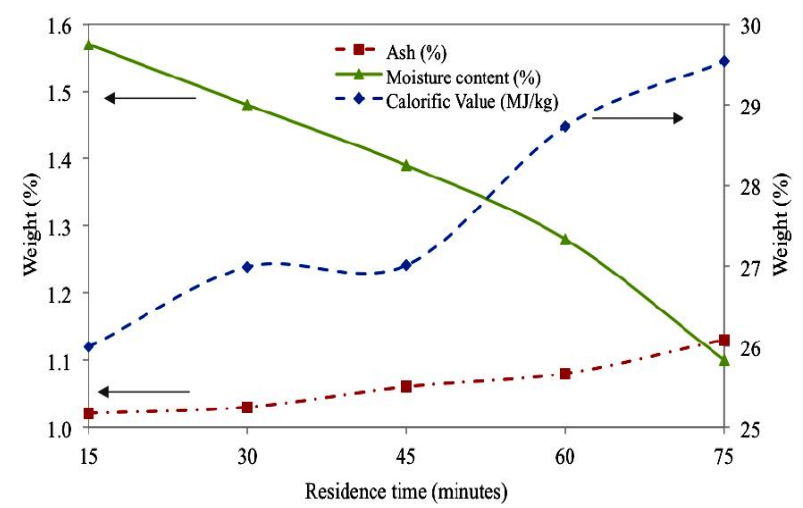

Fig. 5. The influence of the carbonization residence time on the calorific value, moisture content, and ash content of the resulting charcoals at the temperature of $673 \mathrm{~K}$ and particle size of $5 \mathrm{~mm}$ [31]

On the contrary, the higher the residence time of the pyrolysis process, the lower the moisture content in the charcoal. The moisture content of the charcoal was found to be $1.57-1.10 \%$ in the range of $15-75 \mathrm{~min}$.

The pyrolysis temperature affects the composition of the product. Fig. 6 shows the charcoal calorific value, moisture content, and ash content at different temperatures. The highest calorific value of $29.15 \mathrm{MJ} / \mathrm{kg}$ was obtained at a maximum temperature of $723 \mathrm{~K}$, and the lowest $24.73 \mathrm{MJ} / \mathrm{kg}$ at $523 \mathrm{~K}$. The highest ash content of $1.1 \%$ was recorded at the highest temperature of 723 Kand the lowest ash content of $1.01 \%$ - at $523 \mathrm{~K}$. The moisture content at the stated temperature was found to be 2.43 and $1.21 \%$, respectively.

Based on the observations made, $673 \mathrm{~K}$ is the best temperature that gave good yield and calorific value.

The particles size of biomass greatly affects the heating rate of solid fuel. The effect of the biomass particle on the charcoals quality parameters was noticed in Fig. 7. be considered a promising renewable energy source for combined heat and power generation for the Brazilian agro-food industry [30].

Ahmad et al. [31] described the results about the influence of pyrolysis process conditions on the quality of coconut shells charcoal.

Fig. 5 shows the influence of the carbonization residence time on the charcoal calorific value, moisture content, and ash content at a constant temperature of $673 \mathrm{~K}$ and particle size of $5 \mathrm{~mm}$. The ash content and the calorific value of the charcoal increased from 1.02 to $1.13 \%$ and from 25.99 to $29.54 \mathrm{MJ} / \mathrm{kg}$, respectively, with increasing carbonization residence time. The heat content of the charcoal was found to be high at higher temperatures and vice versa.

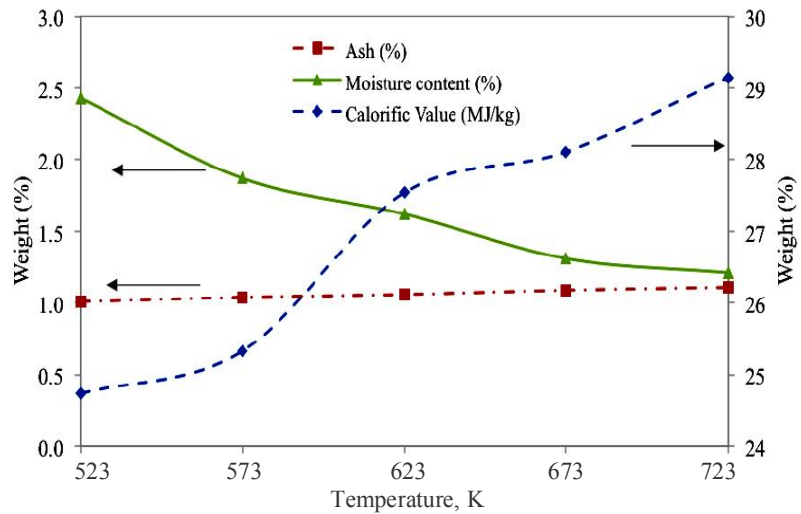

Fig. 6. The influence of the carbonization temperature on the calorific value, moisture content, and ash content of the resulting charcoals at the duration of $60 \mathrm{~min}$ and particle size of $25 \mathrm{~mm}$ [31]

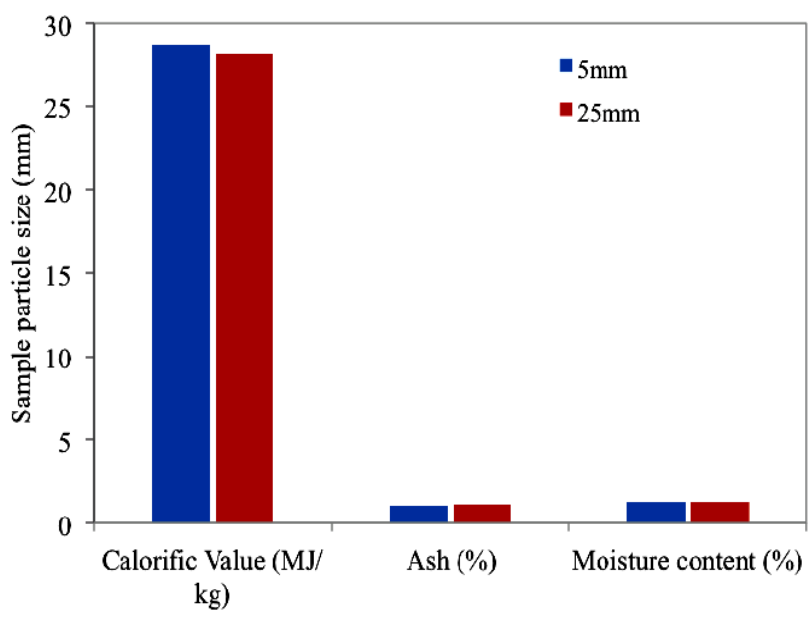

Fig. 7. The influence of the biomass particle size on the calorific value, moisture content, and ash content of the resulting charcoal at the temperature of $673 \mathrm{~K}$ and residence time of $60 \mathrm{~min}$ [31] 
At the same temperature and residence time, the calorific value and the ash content values are higher for the smaller particles size. The calorific value and the ash content for the particles size of $5 \mathrm{~mm}$ are $28.73 \mathrm{MJ} / \mathrm{kg}$ and $1.08 \%$, respectively; for the particles size of $25 \mathrm{~mm}$ these values are $28.11 \mathrm{MJ} / \mathrm{kg}$ and $1.09 \%$, respectively. It was found that the moisture contents were $1.28 \%$ and $1.31 \%$ for the particles of $5 \mathrm{~mm}$ and $25 \mathrm{~mm}$, respectively.

The work [32] focused on analyzing the effect of process parameters (feedstock particle size, initial mass, and the residence time of gas released during the devolatilization) on the mass and fixed carbon yields of charcoal produced (Table 10).

The influence of the initial mass on char and FC yield can be clearly observed by comparing the data between columns 1 and 2 with columns 3 and 4, respectively. In the case of spruce GROT (top and branches) for example, the char and FC yield significantly increased by $39.1 \%$ from $20.59 \%$ (column 1) to $28.64 \%$ (column 3) and from $18.03 \%$ (column 2) to $25.08 \%$ (column 10), respectively.

Similar trends are observed for the birch GROT with lower increase percentages of $32.81 \%$ and $32.79 \%$ for the char and FC yields, respectively. The trends are also valid for the case of spruce stem wood, but not birch stem wood. The positive effect of increasing initial mass of feedstock on the yields can be attributed to the catalytic formation of secondary char due to longer contact time between pyrolysis gas and char during carbonization, except for the unexpected results of the birch wood case, the reason of which is unknown. Similar to the case of birch wood tests with different initial masses, no consistent trend was observed as expected when increasing the feedstock particle size from $(63 \mu \mathrm{m}<d<100 \mu \mathrm{m})$ to $(d<1 \mathrm{~mm})$. This can be examined by comparing the (no lid) data of column 3 versus 7, and column 4 versus 8 (no lid), as well as even the (with lid) data of column 5 versus 9 , and column 6 versus 10 . It is to say that the yield changes from case to case varied up and down within $\pm 13 \%$, and the reason is unknown.

Let us now compare the data of columns 3 versus 5 , and columns 4 versus 6 for the small particle size $(63 \mu \mathrm{m}<d<100 \mu \mathrm{m})$ and columns 7 versus 9, and columns 8 versus 10 for the large particle size $(d<1 \mathrm{~mm})$ to evaluate the effect of the pyrolysis gas confinement in the reactor. Interestingly, for all cases the effect is positive. The most significant improvements in char and FC yields are observed for the test of birch GROT with the large particle size $(d<1 \mathrm{~m} \mathrm{~m})$. Indeed, the char and FC yields increased by $33.83 \%$ and $32.04 \%$, respectively, from $21.96 \%$ (column 7) to $29.39 \%$ (column 9) and $19.10 \%$ (column 8 ) to $25.22 \%$ (column 10 ).
In general, the results from the lid tests can be explained by the fact that the escape of nascent pyrolysis gas from the sample was hindered by the lid and the residence time of the gas in the matrix and vicinity of the solid carbon residues was increased. It has been reported beneficial effects of increased vapor-phase residence times and increased vapor concentrations on favoring char formation and char yields [33,34]. The reason for this is that keeping the released pyrolysis gas in contact with both decomposing solid biomass and the solid mass products has the effect of secondary tar reactions taking place inside the crucible, forming the secondary char and increasing the char yield.

Bui et al. [35] investigated the $\mathrm{CO}_{2}$ gasification reactivity of Norwegian Spruce charcoals from stem wood and its forest residue produced at different pressures. After cutting into small pieces and drying at $378 \mathrm{~K}$ for $24 \mathrm{~h}$, the raw samples were subjected to flash carbonization at about $773 \mathrm{~K}$ and different pressures of 0.79 and $2.17 \mathrm{MPa}$. Characteristics of the produced charcoals are given in Table 11.

The gasification behavior of charcoals towards $\mathrm{CO}_{2}$ was investigated by using TGA. The sample was heated from room temperature to different gasification temperatures of 1073,1123 and $1223 \mathrm{~K}$ with a heating rate of $13 \mathrm{~K} / \mathrm{min}$ under a nitrogen flow of $100 \mathrm{ml} / \mathrm{min}$. After reaching the gasification temperature, the nitrogen flow was replaced by a $\mathrm{CO}_{2}$ flow with the same flow rate. The charcoal gasification was maintained until a constant weight was reached. In this study two kinetic models, the random pore model (RPM) and overlapped grain model (OGM), were employed for kinetic modelling and simulation [36, 37].

The extracted kinetic parameters together with fit quality at $1123 \mathrm{~K}$ for all charcoals are shown in Table 12.

It can be observed that the two kinetic models represent well the experimental data. However, the OGV was better regarding fit quality. The extracted kinetic parameters from the two kinetic models were similar to each other. For instance, the activation energy of spruce charcoal produced at $0.79 \mathrm{MPa}$ was about $222 \mathrm{~kJ} / \mathrm{mol}$ obtained from the RPM, whereas it was about $224 \mathrm{~kJ} / \mathrm{mol}$ for the OGM.

Wang et al. [38] studied the effect of storage time and conditions on the properties of the woody charcoal were. It was observed that the volatile content of the collected charcoal samples generally increased along the storage time, whereas the fixed carbon content of the samples decreased on average by about $3 \%$. Findings of this work indicate that properties of charcoal might change considerably after storage and transportation time. Such changes are related to storage conditions, and charcoal properties and size. 
Char yields and fixed carbon yields [32]

\begin{tabular}{|c|c|c|c|c|c|c|c|c|c|c|}
\hline \multirow{4}{*}{ Sample } & \multirow{2}{*}{\multicolumn{2}{|c|}{$\begin{array}{l}\text { Initial mass: } 1 \mathrm{mg} ; \\
63 \mu \mathrm{m}<d<100 \mu \mathrm{m} \\
\text { No lid }\end{array}$}} & \multicolumn{4}{|c|}{$\begin{array}{l}\text { Initial mass: } 10 \mathrm{mg} \\
63 \mu \mathrm{m}<d<100 \mu \mathrm{m}\end{array}$} & \multicolumn{4}{|c|}{$\begin{array}{c}\text { Initial mass: } 10 \mathrm{mg} ; \\
\quad d<1 \mathrm{~mm}\end{array}$} \\
\hline & & & & & & & & & & \\
\hline & 1 & 2 & 3 & 4 & 5 & 6 & 7 & 8 & 9 & 10 \\
\hline & $y_{\text {char }}$ & $y_{f c}$ & $y_{\text {char }}$ & $y_{f c}$ & $y_{\text {char }}$ & $y_{f c}$ & $y_{\text {char }}$ & $y_{f c}$ & $y_{\text {char }}$ & $y_{f c}$ \\
\hline Spruce GROT & 20.59 & 18.03 & 28.64 & 25.08 & 30.44 & 26.56 & 26.65 & 23.34 & 30.24 & 26.38 \\
\hline Spruce wood & 14.93 & 14.26 & 17.74 & 16.94 & 23.90 & 22.33 & 19.52 & 18.64 & 22.21 & 20.75 \\
\hline Birch GROT & 18.93 & 16.47 & 25.14 & 21.87 & 32.89 & 28.22 & 21.96 & 19.10 & 29.39 & 25.22 \\
\hline Birch wood & 16.78 & 15.68 & 16.04 & 14.98 & 20.56 & 18.71 & 17.68 & 16.52 & 20.49 & 18.65 \\
\hline
\end{tabular}

Table 11

Proximate and ultimate analysis of charcoal samples [35]

\begin{tabular}{|c|c|c|c|c|c|c|c|c|c|}
\hline \multirow{2}{*}{ Samples } & \multirow{2}{*}{ Pressure, bar } & \multicolumn{3}{|c|}{ Proximate analysis } & \multicolumn{5}{|c|}{ Ultimate analysis } \\
\cline { 3 - 10 } & & VM & Ash & FC & C & H & N & S & O \\
\hline \multirow{2}{*}{ Spruce } & 7.9 & 18.1 & 1.7 & 80.2 & 77.35 & 3.68 & 0.29 & $<0.02$ & 18.66 \\
\cline { 2 - 11 } & 21.7 & 18.8 & 1.1 & 80.1 & 76.36 & 3.50 & 0.47 & $<0.02$ & 19.55 \\
\hline \multirow{2}{*}{ Spruce GROT } & 7.9 & 13.1 & 6.1 & 80.7 & 83.49 & 2.65 & 0.56 & $<0.02$ & 13.28 \\
\cline { 2 - 11 } & 21.7 & 28.5 & 3.7 & 67.7 & 77.34 & 3.79 & 0.66 & $<0.02$ & 18.19 \\
\hline
\end{tabular}

Table 12

Extracted kinetic parameters from the RPM and OGM [35]

\begin{tabular}{|c|c|c|c|c|c|c|c|c|c|}
\hline \multirow{2}{*}{ Sample } & \multirow{2}{*}{ Pressure, MPa } & \multicolumn{4}{|c|}{ RPM } & \multicolumn{4}{c|}{ OGM } \\
\cline { 2 - 10 } & & $A, \mathrm{~min}^{-1}$ & $E_{a}, \mathrm{~kJ} / \mathrm{mol}$ & $\psi$ & Fit, $\%$ & $A, \mathrm{~min}^{-1}$ & $E_{a}, \mathrm{~kJ} / \mathrm{mol}$ & $\varepsilon_{0}$ & Fit, \% \\
\hline \multirow{2}{*}{ Spruce } & 0.79 & $8.78 E+08$ & 222.21 & 5.37 & 98.62 & $1.06 E+09$ & 222.40 & 0.46 & 99.04 \\
\cline { 2 - 11 } & 2.17 & $1.63 E+08$ & 210.50 & 3.98 & 98.97 & $1.90 E+08$ & 210.56 & 0.56 & 99.27 \\
\hline \multirow{2}{*}{ Spruce GROT } & 0.79 & $2.08 E+09$ & 229.61 & 4.59 & 97.55 & $2.47 E+09$ & 229.76 & 0.50 & 98.01 \\
\cline { 2 - 11 } & 2.17 & $5.87 E+08$ & 215.15 & 3.79 & 98.58 & $6.97 E+08$ & 215.42 & 0.58 & 98.81 \\
\hline
\end{tabular}

\section{Carbonization Technologies}

In works $[39,40]$ the main kilns used worldwide for the production of charcoal were characterized. A total of 21 types of carbonization kilns (172 carbonization kiln patents) were found, and the majority presents technological improvements. However, even with carbonization kilns with technological advances available (information on the structure of the kiln, means of mechanizing the loading and unloading of kiln, the reuse of gases and vapors from the carbonization process, control of the carbonization process, rapid cooling of the produced charcoal while it is still inside the kiln), most of the world charcoal production still uses from traditional kilns with low technology, which results in worse charcoal yield and quality.

Three types of heating to initiate the carbonization and maintain high temperatures during the processes are generally used [41]:

- Internal heating, where part of the raw material is burnt under controlled air flow. More than $90 \%$ of the charcoal technologies employ internal heating based on the partial combustion of the feedstock to manufacture charcoal. The kiln design is simple and the investment costs are usually low, especially for small producers [42].

- External heating where the retort is heated from the outside and no oxygen enters the reactor. These technologies are few and expensive.

- Heating with recirculated gas, where pyroligneous vapors are burnt in an external combustion chamber and directed into the reactor where it is in direct contact with the raw material. The Lambiotte [43-45] carbonization process is the most known continuous process (Fig. 8).

The retort has the shape of a vertical cylinder with a fed opening at the top and a discharge cone at the bottom. Wood is transported to the top of the retort by a hoist and enters the retort through a lock-hopper. On its way down, the wood passes three zones, that is the drying, the carbonization and the cooling zone.

The DPC (drying-pyrolysis-cooling) technology $[46,47]$ in Brazil uses principle of heating with recirculated gas as well. The basic concepts of the DPC process are: 

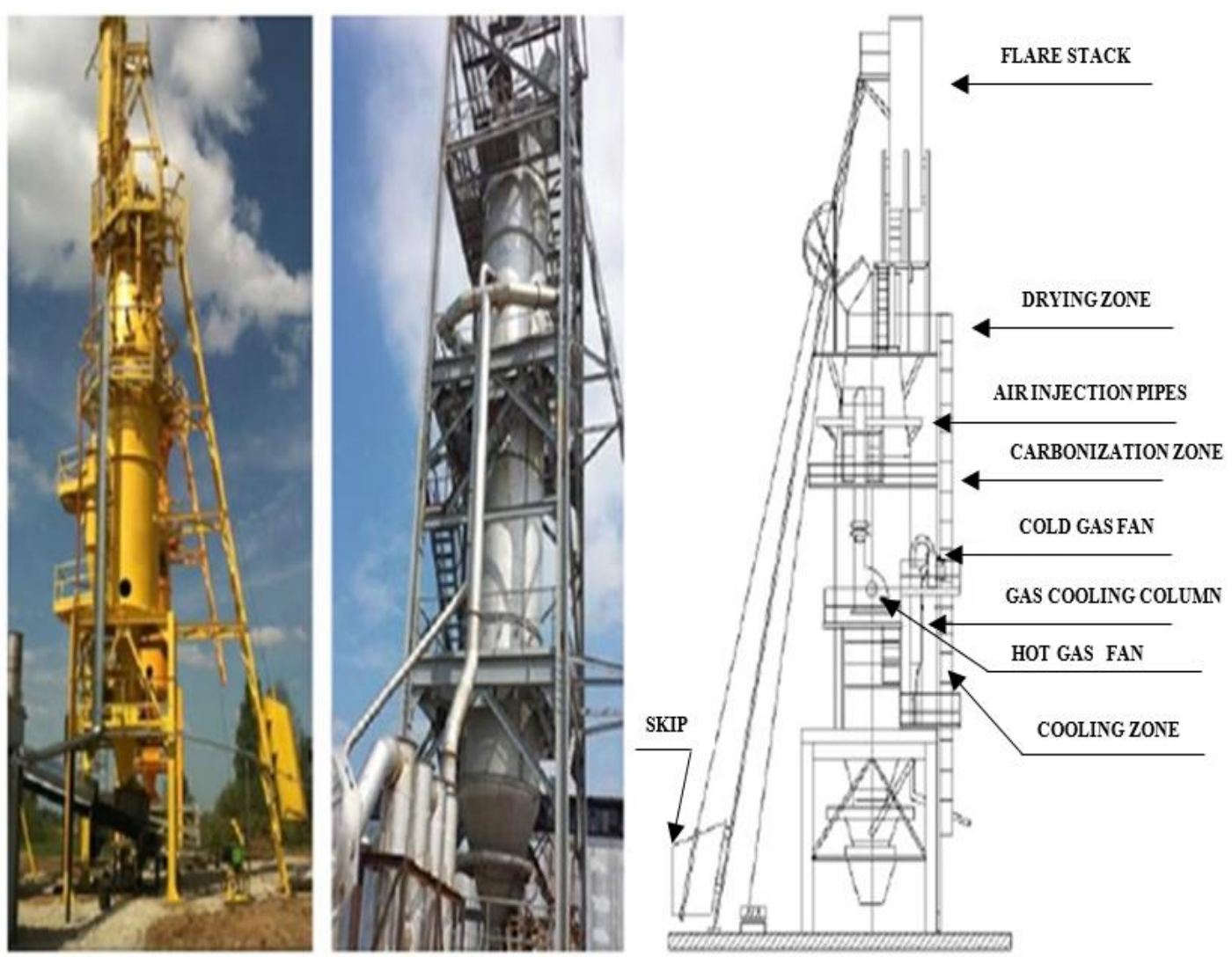

Fig. 8. Lambiotte technology [45]

$\rightarrow$ Utilization of the emitted gases - condensable and noncondensable - as a source of the thermal energy required by the carbonization process.

$\rightarrow$ Utilization of gases emitted during the pyrolysis step as a heart carrier for the endothermic stage of the pyrolysis.

The functions of wood drying, pyrolysis and the charcoal are performed simultaneous and independently into at least three reactors. The emitted gases during pyrolysis with a significant heating value are burned in a combustion chamber, generating hot gases which are transported to the reactor performing the wood drying.

Carbonex [48] is the latest technology on the market totally automated. This company developed, designed, built and started a complete installation from the preparation of wood; reception, cutting and drying, to high-efficiency charcoal and electricity production (1.4 MWe) from the pyrolysis gases.

Zola et al. [49] presented multiple criteria decisionmaking (MCDM) method to select a proper charcoal kiln by taking into consideration the industry's know how and needs. To solve this problem with the influence of the decision-maker, the Analytic Hierarchy Process (AHP) method was chosen to evaluate the criteria's weight. Furthermore, to allow the decision-maker to analyze both, quantitative and qualitative criteria, the best alternative was chosen by using the Fuzzy Technique for Order Preference by Similarity to Ideal Solution (TOPSIS) method. Finally, the method that allows the decision maker to play a crucial role in the process was proposed. Combined with AHP, the fuzzy TOPSIS method made it possible to list the most suitable alternative within the considered industry conditions. Conclusively, the method generates different results for each case decision maker, showing it to be a successful tool for the charcoal industry to select the best kiln, thus boosting the production of renewable energy.

\section{Conclusions}

Charcoal is used to produce chemicals and diverse pharmaceuticals products. It is also used in refining metals, for the manufacture of fireworks, production of activated carbon, and domestic cooking and heating. Nowadays, more than 50 million tons ofcharcoal was produced globally 
Charcoal yield and quality are related to biomass types and their characteristics such as size, physical properties and proportion of chemical components. Moreover, charcoal quality is strongly affected by process parameters such as temperature of carbonization, heating rate, level of oxygen, and pressure. Besides, the charcoal quality is assessed by the proximate analysis, elemental analysis, calorific value, etc.

It was shown that the most of the world charcoal production still uses traditional kilns with low technology, which results in worse charcoal yield and quality.

\section{Symbols}

$\mathrm{M}$ - total moisture, $\%$;

$\mathrm{ASH}$ - ash content, $\%$;

$\mathrm{VM}$ - volatile matter, \%;

$\mathrm{FC}$ - fixed carbon, $\%$;

$\mathrm{C}$ - content of carbon, $\%$;

$\mathrm{HHV}$ - high heating value,

$\mathrm{MJ} / \mathrm{kg}$;

$y_{\text {char }}-$ yield of char, $\%$;

$y_{f c}-$ yield of fixed carbon, $\%$; RPM - random pore model; OGM - overlapped grain model;

\author{
$\mathrm{H}$ - content of hydrogen, $\%$; \\ $\mathrm{N}$ - content of nitrogen, $\%$; \\ $\mathrm{S}$ - content of sulfur, \%; \\ $\mathrm{O}$ - content of oxygen, $\%$; \\ $\mathrm{H} / \mathrm{C}, \mathrm{O} / \mathrm{C}$ - atomic ratios; \\ $A$-preexponential factor, \\ $\min ^{-1}$; \\ $E_{a}$ - energy of activation, \\ $\mathrm{KJ} / \mathrm{mol}$; \\ $\psi$-structural parameter \\ related to the pore structure \\ and surface area of initial \\ char samples
}

\section{References}

[1] Altun N., Hiçyılmaz C., Kök M.: J. Anal. Appl. Pyrolysis, 2003, 67, 369. https://doi.org/10.1016/S0165-2370(02)00075-X

[2] Shuping Z., Tulong W., Minde Y. et al.: Bioresource Technol., 2010, 101, 359. https://doi.org/10.1016/j.biortech.2009.08.020 [3] Pyshyev S., Prysiazhnyi Yu., Shved M. et al.: Crit. Rev. Envir. Sci. Tech., 2017, 24, 2387.

https://doi.org/10.1080/10643389.2018.1426968

[4] Prysiazhnyi Yu., Shved M., Pyshyev S. et al.: Chem. Chem. Technol., 2018, 12, 355. https://doi.org/10.23939/chcht12.03.355 [5] Malovanyy M., Petrushka K., Petrushka I.: Chem. Chem. Technol., 2019, 13, 372. https://doi.org/10.23939/chcht13.03.372 [6] Food and Agricultural Organization. Forestry Production and Trade; FAO: Rome, Italy, 2019.

[7] WorldWildlife Fund. The Dirty Business of Barbecue Charcoal;WorldWildlife Fund: Washington, DC, USA,2019.

[8] Bailis R., Rujanavech C., Dwivedi P. et al.: Energy Sustain. Dev., 2013,17, 189. https://doi.org/10.1016/j.esd.2012.10.008

[9] Pereira E., Martins M., Pecenka R. et al.: Renew. Sustain. Energy Rev.,2017, 75, 592.

https://doi.org/10.1016/j.rser.2016.11.028

[10] The Forest Trust. Charcoal TFT Research.

http://www.tftearth.org/wp-content/uploads/2015/05/TFT-charcoalresearch.pdf

[11] MacroMarket. Wood Charcoal (Including Shell or Nut Charcoal). https://macro.market/product/09440200

[12] Observatory of Economic Complexity. Wood Charcoal (Including Shell or Nut Charcoal).

https://oec.world/en/profile/hs92/440200/
[13] International Energy Agency. What is Energy Security?

International Energy Agency: Paris, France, 2018.

[14] United States Chamber of Commerce. International Index of Energy Security Risk. Assessing Risk in a GlobalEnergy Market. https://www.globalenergyinstitute.org/sites/default/files/energyrisk intl 2016.pdf

[15] Industrial charcoal making. Food and agriculture organization of the United Nations. Rome, 1985, 142.

[16] Pereira B., Oliveira A., Carvalho A. et al: : Int. J. Forestry Res., 2012, 523025. https://doi.org/10.1155/2012/523025

[17] Nhuchhen D., Afzal M.: Bioengineering, 2017, 4, 7.

https://doi.org/10.3390/bioengineering 4010007

[18] Jigisha P., Channiwala S., Ghosal G.: Fuel, 2005, 84, 487. https://doi.org/10.1016/j.fuel.2004.10.010

[19] Briseno-Uribe K., Carrillo Parra A., Bustamante-Garcia V. et al.: Int. J. Green Energ., 2015, 12, 961.

https://doi.org/10.1080/15435075.2014.891121

[20] Oyedun A., Lam K., Hui C.: Chinese J. Chem. Eng., 2012, 20, 455. https://doi.org/10.1016/S1004-9541(11)60206-1

[21] Bustos-Vanegas J., Martins M., Freitas A. et al.: Fuel, 2019,

244, 412. https://doi.org/10.1016/j.fuel.2019.01.136

[22] Somerville M., Deev A..: Renew. Energ., 2020, 151, 419. https://doi.org/10.1016/j.renene.2019.11.036

[23] Kluska J., OchnioM., Kardas D.: Waste Manage., 2020, 105, 560. https://doi.org/10.1016/j.wasman.2020.02.036

[24] Zhang X., Yuan Z., Yao Q. et al.: Bioresour. Technol., 2019, 290, 121800. https://doi.org/10.1016/j.biortech.2019.121800

[25] Takada M., Niu R., Minami E. et al.: Biomass Bioenerg., 2018, 115, 130. https://doi.org/10.1016/j.biombioe.2018.04.023

[26] Fu P., Yi W., Bai X. et al.: J. Bioresour. Technol., 2011, 102,

8211. https://doi.org/10.1016/j.biortech.2011.05.083

[27] Chun Y., Sheng G., Chiou C. et al.: Environ. Sci. Technol., 2004, 166, 500. https://doi.org/10.1021/es960481f

[28] Ahmad M., Lee S., Dou X. et al.: Bioresour. Technol., 2012,

118, 536. https://doi.org/10.1016/j.biortech.2012.05.042

[29] Demirbas A.: Energy, 1999, 24, 141.

https://doi.org/10.1016/S0360-5442(98)00077-2

[30] Miranda M., Veras C., Ghesti G: Waste Manage., 2020, 103,

177. https://doi.org/10.1016/j.wasman.2019.12.025

[31] Ahmad R., Sulaiman S., Yusuf S. et al.: Platform: A Journal of Engineering, 2020, 4, 73.

[32] Tran K.-Q., Alonso M., Wang L. et al.: Energy Procedia, 2017, 105, 787. https://doi.org/10.1016/j.egypro.2017.03.390

[33] Wang L., Skreiberg O., Gronli M. et al.: Energ. Fuel., 2013, 27, 2146. https://doi.org/10.1016/j.egypro.2017.03.390

[34] Di Blasi C.: Prog. Energ. Combust., 2008, 34, 47.

https://doi.org/10.1016/j.pecs.2006.12.001

[35] Bui H.-H., Wang L., Tran K.-Q. et al.: Energy Procedia, 2017, 105, 316. https://doi.org/10.1016/j.egypro.2017.03.320

[36] Liu H. et al.: Energ. Fuel., 2003, 17, 961.

https://doi.org/10.1021/ef020231m

[37] Adschiri T, Kojima T, Furusawa T.: Chem. Eng. Sci., 1987, 42, 1319. https://doi.org/10.1016/0009-2509(87)85005-4

[38] Wang L., Barta-Rajnai E., Hu K.: Energy Procedia, 2017,105, 830. https://doi.org/10.1016/j.egypro.2017.03.397

[39] Rodriges T., Braghini Jr. A.: J. Anal. Appl. Pyrolysis, 2019, 143, 104670. https://doi.org/10.1016/j.jaap.2019.104670

[40] Rodriges T., Braghini Jr. A.: Renew. Sustain. Energ. Rev., 2019, 111, 170. https://doi.org/10.1016/j.rser.2019.04.080

[41] Gronli M.: Industrial production of charcoal. SINTEF Energy Research. 1999. N-7465. Trondheim. Norway.

[42] Kammen D., Lew D. (Eds.): Renewable and Appropriate Energy Report. National Renewable Energy Laboratory: University of California, Berkeley 2005. 
[43] Lambiotte A.: Pat. US2289917A, Publ. July 14, 1942.

[44] Emrich W.: Handbook of Charcoal Making - the Traditional and Industrial Methods. Springer 1985. https://doi.org/10.1007/97894-017-0450-2

45] Kajina W., Junpen A., Garivait S.: J. Sustain. Energ. Environ., 2019, 10, 19 .

[46] Lucio A., Santos S.: Proceed. $2^{\text {nd }}$ International Meeting on Ironmaking and $1^{\text {st }}$ International Symposium on Iron Ore. ABM Publishers, Sao Luis City-Maranhao State Brazil, 2004, 2, 1133. [47] Lucio A, Viera S: 45 Seminario de Reducao de Minerio de Ferro e Materias-primas, ABM. Rio de Janeiro 2015, RJ, Brazil. [48] http://carbonex.fr/home.html

[49] Zola F., Colmenero J., Aragao F. et al.: Energy, 2020, 190, 116377. https://doi.org/10.1016/j.energy.2019.116377

Received: October 08, 2019 / Revised: October 23, 2019 / Accepted: January 12, 2020

\section{ВИРОБНИЦТВО ДЕРЕВНОГО ВУГІЛЛЯ: ОГЛЯД}

Анотація. Проаналізовано застосування деревного вугілля (ДВ) у різних галузях промисловості та сучасні уявлення про чинники, які впливають на процес отримання ДВ. Описано вплив характеристик (розмір, фізичні властивості, хімічний склад) й природи вихідної сировини (деревина чи сільськогосподарські відходи), температури карбонізачії, ивидкості нагрівання, рівню кисню та тиску на вихід і якість ДВ. Проведено аналіз існуючих технологій виробничтва деревинного вугілля та їх класифікаиію за типом ініціювання нагріву $і$ підтримуванням температури впродовж процесу карбонізації. Розглянуто процеси виробництва деревинного вугілля Lambiotte, DPC ma Carbonex.

Ключові слова: деревне вугілля, біоресурси, технологія виробниитва деревного вугілля, піч, якість. 